https://doi.org/10.18485/iipe_euchanges.2021.ch4

\title{
ENERGY SECURITY ISSUES: RESHAPING EUROPEAN REGIONAL SECURITY PATTERNS?
}

\begin{abstract}
Nevena ŠEKARIĆ ${ }^{1}$
Abstract: European energy security is one of the most dynamic areas where many challenges have lately occurred, especially when it comes to natural gas. Politicization and securitization of this energy issue resulted in many changes within the European energy policy, such as re-orientating attention towards diversifying energy routes and suppliers and decarbonising economies. Considering the peculiar regional dimension of relevant pipelines and their effects on regional security dynamics, the main research question could be defined as follows: Do the energy security issues have the potential to transform European regional security patterns? European energy security dynamics is analyzed through two case studies regarding the Nord Stream 2 issue and the recent energy clash on natural gas in the Eastern Mediterranean. According to the defined research question and the research topic, the analysis is done through the Regional Security Complex Theory' lenses and the concepts of energy governance and energy diplomacy viewed through the recently established Energy Union. The roles of dominant energy players within European energy security are examined, and the role of natural gas as well in the context of its potential to transform established regional security patterns, both internally and externally. The analysis employs a review of the respective literature and also an analysis of key political statements and media releases, and it is
\end{abstract}

\footnotetext{
${ }^{1}$ Research Assistant, Institute of International Politics and Economics, Belgrade. E-mail: nevena.sekaric@diplomacy.bg.ac.rs

The paper presents findings of a study developed as a part of the research project "Serbia and challenges in international relations in 2021", financed by the Ministry of Education, Science, and Technological Development of the Republic of Serbia, and conducted by Institute of International Politics and Economics, Belgrade.
} 
made in regard to key theoretical guidelines. The results of the conducted analysis support the affirmative answer to the proposed research question. Keywords: energy security, the EU, energy governance, energy diplomacy, the Energy Union, the Nord Stream 2, the Eastern Mediterranean.

\section{INTRODUCTION}

Following the trend of included non-military threats into a security agenda after the Cold War, energy-related topics find their own place within contemporary security studies. While many observations by the late 90 s and early 2000s were concentrated around oil when it comes to the energy security theme, natural gas issues seem to be ascending to the top of political and security agendas. By the time of writing this paper, the ubiquitous COVID pandemic has demonstrated the decline of the oil security concerns and raised attention over the gas issues and the overall need for decarbonising economies.

With the global increase of energy dependence and resource scarcity, energy-related issues became one of the most critical security concerns, whether on a state or supranational level. The EU is only one of many in addressing these concerns. The fact that the EU is not an energy-rich subject, presenting at the same time one of the world's largest gas consumers, makes the question of secure and continuous supply of this resource one of its top priorities. As shown by Mišík (2019), natural gas has a prominent place in European external energy relations due to its political and technical specificities. Considering that the EU is importing the majority of gas from only a few countries, ${ }^{2}$ where Russia is dominant, the necessity for new suppliers became one of the main tasks over time. Besides, diversifying transportation routes and energy producers or consumers reduces the possibilities to use energy resources as a political pressure tool. The involvement of other actors (such as private companies, investors, regulators, etc.), apart from supranational and nationals, additionally makes this question very complex.

In the context of the above-mentioned, the aim of this paper is to examine state-of-play within the EU in the domain of energy security. Employing a theoretical framework in the form of concepts of energy governance and energy diplomacy and Regional Security Complex Theory (hereinafter RSCT)

2 Besides Russia, the main gas suppliers of the EU both in 2019 and 2020 are Norway and, to some extent, Algeria (EU imports of energy products, 2020). 
as well, current European energy security dynamics will be analysed in order to answer the question referring to the potential of energy-related issues to transform the established European regional security patterns.

\section{REGIONAL SECURITY COMPLEX THEORY: POSSIBLE EVOLUTIONS OF THE ESTABLISHED REGIONAL SECURITY STRUCTURES}

RSCT, originally developed by the Copenhagen School of security studies theorists, sees the regional level as the most prominent for analysing security issues and dynamics. Based on the stance that the regional security complex (hereinafter RSC) refers to the 'set of units whose major processes of securitization, desecuritization, or both are so interlinked that their security problems cannot reasonably be analysed or resolved apart from one another' (Buzan and Wæver, 2003, p. 44), the authors claim that the key security dynamics is being established within regions (primarily in form of an internal regional security dynamics). Starting from this point, the rest of the paper examines internal dynamics, followed by the analysis of external European regional security dynamics, both being concentrated around natural gas issues. Sketching main theoretical presumptions will help to conduct analysis in order to answer the research question.

Considering that the region represents 'a sufficiently dynamic framework for changing of its key characteristics' (Lipovac, 2016, p. 98), the possibility of the transformation of its established patterns is not excluded from the analysis. Some studies analysed possible scenarios when it comes to the changes within the EU-Russia energy relations (Kirchner and Berk, 2010) or possible transformations of European regional security complex' patterns (Adamides and Christou, 2015; Bogaert, 2019). These possible transformations arise from the potential changes of the security interdependence between units of RSC or within the interregional level.

Key characteristics of RSC form its essential structure. These characteristics (or variables) exist in the form of boundaries of RSC, its anarchic structure, polarity, and social construction (amity-enmity spectrum) (Buzan and Wæver, 2003, p. 53). In relation to these variables, there are three possible evolutions of the established regional security structures. ${ }^{3}$ According

${ }^{3}$ In relation to these variables and evolutions, there are different types of RSCs. In the view of polarity, there are unipolar, bipolar, tripolar and multipolar complexes, while the criterion of power distinguishes between standard and centred 
to Buzan and Wæver, these evolutions could be realized in the forms of the maintenance of the status quo, internal and external transformation of RSC (2003, p. 53). Maintenance of the status quo refers to the absence of any significant changes within the essential structure of a complex. In the context of this research, this scenario would mean that the EU does not perceive its energy situation as challenging and problematic, and thus it is not eager to undertake any actions to change it. The internal transformation refers to the changes in essential structure within the existing boundaries of a complex. More concrete, the internal transformation could be analysed along the line fragmentation-integration (as suggested by the theory) of internal energy security dynamics, which additionally will be examined employing the concepts of energy governance and energy diplomacy. Finally, the external transformation refers to the changes in essential structure by expanding or contracting the outer boundaries of a complex. ${ }^{4}$ According to the identified research topic, the external transformation would mean that e.g., diversification efforts create new forms of stronger security interdependence between units of different complexes. In order to examine possible transformational trajectories of established regional security patterns, European energy security dynamics (both internally and externally) should be analysed according to key theoretical and conceptual guidelines. In order to do so, internal energy dynamics will be examined firstly through the lenses of the concepts of energy governance and energy diplomacy, followed by questioning the external transformation of established European regional security patterns by employing two case studies regarding the latest European energy security dynamics.

\section{FROM ENERGY GOVERNANCE TOWARDS ENERGY DIPLOMACY: THE EUROPEAN ENERGY UNION}

Liberalization and market logic have been key elements of the European energy policy since the end of the 1980s. However, many contemporary

complexes. According to the amity-enmity patterns, there are three types of RSCs: security community, security regime, and conflict formation (Buzan and Wæver, 2003, pp. 53-57). Applying all these criteria, today's complex centred around the EU presents a centred complex around one institution (i.e., the EU), in the form of a security community.

${ }^{4}$ The external transformation of the European regional security complex in the form of exclusion of the United Kingdom did happen, but it is not included in the analysis due to its deeply political roots having no relations with energy-related issues. 
challenges linked with the global energy environment, such as resource scarcity, the so-called 'resource nationalism', growing competitiveness from 'new' energy players (primarily China and India), and uneven distribution of key energy resources resulted in the EU's shift towards reconceptualizing its energy policy priorities. Deterioration in (energy) relations with Russia and several gas disputes during the 2000s contributed to this complex situation and changed the focus of the EU from its internal energy market towards energy relations with suppliers and transit states. As Szulecki and Westphal noted, the EU is torn between two challenges nowadays - the first linked to the balancing of three energy policy goals (securing stable supply, maintaining economic competitiveness, and safeguarding environmental sustainability), and the second one existing in the form of tensions between 'growing European harmonization with increased competences of the European Commission and the principle of Member State sovereignty over national energy mixes' (2018, pp. 177-178). As will be presented in the following text, this everlasting balancing marked the process of creating a European energy policy over time.

As simply explained by Lavenex and Schimmelfennig, the external energy governance represents 'the expansion of EU rules beyond EU borders' $\left(2009\right.$, p. 807). ${ }^{5}$ In addition, the EU's external energy approach was aimed to develop a common regulatory space with other regions, accompanied by its 'attractiveness' to the non-member states (Prange-Gstohl, 2009). As it could be seen, this concept was traditionally linked to the EU given the fact that the EU's energy policy was created around the liberal model where energy authorities were mainly private companies rather than national states and governments (Youngs, 2011, p. 51). These first energy policy steps were concentrated around regulating competition and market rules but did not sufficiently consider the security momentum in the supplying process. Over time, the EU starts to take more assertive external energy policy steps, making thus energy diplomacy a becoming part of 'the EU foreign policy vocabulary' (Boersma and Goldthau, 2017, p. 110). Several gas disputes with Russia during the 2000s and the 2014 Ukrainian crisis served as key contextual drivers for the upcoming Commission's actions. Behaviour in the form of energy diplomacy, i.e., the usage of 'foreign policy tools to secure energy

${ }^{5}$ The clearest example of the so-called European 90's energy governance was the Energy Charter Treaty, a tool aiming to spread the EU's energy trade rules beyond its borders. However, this mechanism did not gain much success after the withdrawal of Russia in 2009 and Norway's rejection to ratify it (Avlichou, 2017). 
supplies' (Mišík, 2019, p. 8) thus became a new shape of the EU energy policy. Put differently, the originally market-oriented approach was gradually replaced by the stronger geopolitical. Similarly, as Herranz-Surrallés (2016, p. 1387) noted by showing the evolution of the peculiar paradigm shift, the EU has reinforced its role in external energy relations since the late 2000s, directly promoting external infrastructure diversifying projects and taking a notably bigger role in securing access to external energy sources, significantly bringing closer concepts of energy diplomacy and energy governance. These EU's external moves were further accented by the Ursula von der Leyen's announcement of the new Commission's agenda, where she expressed her pledge to lead a 'geopolitical Commission' and to reinforce the EU's role 'as a relevant international actor' (EP, 2020, p. 1). In order to secure its internal energy needs, the EU put an energy to the top of its priorities and political agenda within its external relations.

Energy issues seemed to be one of the first integration steps when observing the process of European integration, illustrated by the European Coal and Steel Community and the European Atomic Energy Community. Although these 'pillars' were not driven by exclusively energy reasons, ${ }^{6}$ the place of energy in the context of establishing and developing supranational organization should not be neglected. Although the idea of a common energy policy in the EU was present a long time ago, it became significantly important in the past three decades due to rising concerns over the energy and climate issues (Tarnai, 2018, p. 53). The very first step made in regard to settle the political and security background of European energy dependency and to change focus to the external energy relations refers to the Green Paper on the security of energy supply named 'Towards a European Strategy for the Security of Energy Supply' from 2000 (Knodt et al., 2015; Herranz-Surrallés, 2016; Cotella et al., 2016). ${ }^{7}$ Another Green Paper

${ }^{6}$ As Knodt and Ringel (2020) observed, these 'steps should not be misunderstood as first efforts to create a common energy policy'. The main reason for establishing these two out of three 'pillars' was the 'fear of Europe's future becoming like Europe's past if fragmentation and power balancing are allowed to return' (Buzan and Wæver, 2003, pp. 352-353). Fear of going back to the war context and from weapon proliferation left over from the Second World War prevailed at this moment.

${ }^{7}$ A market paradigm and neoliberal ideas were dominant when talking about the EU energy policy back in the 1990s (Herranz-Surrallés, 2016, p. 1388). Gradually, it has been replaced by the external energy policy in the form of energy governance, and, lately, by the bigger involvement of the EU's supranational bodies led by the European Commission in an effort to become a form of energy diplomacy. 
was released in 2006 under the title 'A European Strategy for Sustainable, Competitive and Secure Energy' where the need for a common energy policy was again stressed out by adding the concept of solidarity measures. One of the most important shifts happened in 2009 where the energy policy gained its legal basis (by incorporating it into the EU primary law) after the adoption of the Lisbon Treaty, presenting thus the first transfer of the national states' competences to the EU (Knodt et al., 2015; Tichy, 2019; Knodt and Ringel, 2020). ${ }^{8}$ With the establishment of shared competences between the EU and member states in energy as one of the principal areas (EU, 2007, p. 47), starting from this point, the European Commission is trying to extend its energy competences based on energy diplomacy manner. The power to monitor bilateral agreements between a member state and its energy supplier and stopping the South Stream's construction were the most blatant examples. The legal and institutional basis of the politicized and securitized European energy dependency and louder devotion to the common energy policy were further strengthened by the adoption of many other initiatives, mechanisms, and packages. The most significant among them were the establishment of the Energy Community (entering into force in 2006 and presenting one of the clearest tools of the European energy governance), European Commission's communications from 2007 ('An Energy Policy for Europe') and 2008 ('Second Strategic Energy Review: An EU Energy Security and Solidarity Action Plan'), the Third Internal Energy Market Package (2009), 'Energy 2020: A Strategy for Competitive, Sustainable and Secure Energy' (2010), and European Energy Security Strategy (2014). ${ }^{9}$ The culmination of these pushing efforts made in the EU in regard to achieve a common energy voice with strong security momentum was introducing the Energy Union initiative.

Initially proposed by the then Polish Prime Minister Donald Tusk in 2014, the Energy Union (with the subsequent Diplomacy Action Plan) became one of the top priorities for the upcoming Juncker's Commission agenda. The

\footnotetext{
${ }^{8}$ The so-called 'energy provisions' of the Lisbon Treaty have limited to a significant extent the sovereignty of member states in decision-making regarding energy security issues and provided EU authorities to employ bilateral agreements as an important means of control mechanisms.

${ }^{9}$ There were many other initiatives, packages and decisions made in regard to the European energy security adopted after 2015 (for instance, revised directives on gas supply and the European Green Deal being one of the most important lately) but, due to the lack of space, will not be considered in the context of this paper.
} 
main goal of this energy project is 'to bring all energy related issues [...] under a common "roof" and thus basically create a common EU energy policy' (Mišík, 2019, pp. 81-82). Among five dimensions of this energy policy strategy ${ }^{10}$, special attention is given to the diversifying Europe's sources of energy (under the first dimension) and a fully integrated internal energy market (as the second dimension) (What is the Energy Union about, 2015), giving thus the equal importance to internal and external elements of European energy security. As shown by Avlichou (2017, pp. 20-21), the policy practice prevailing within the EU in the context of energy security after establishing the Energy Union gained more geopolitical meaning, while Franza and Van Der Linde noticed that the Energy Union aims to strengthen the EU's role in external energy policy $(2017$, p. 94). The importance of this project was highlighted by establishing the position of Vice-President of the Energy Union within the European Commission. Calling for the tougher European energy policy stance, the Energy Union as 'the most ambitious energy project since the European Coal and Steel Community' (Šefčovič, 2015) clearly goes beyond traditional energy governance mechanisms.

Some research state that the integration effects of the Energy Union are questionable so far (Herranz-Surrallés et al., 2020, pp. 1-2), not being far from the truth. Nevertheless, the Energy Union stands for a more assertive stance with no doubt and shows the need for the transformation of the European energy reality. Besides, according to some of the latest researches (Tosun and Mišić, 2020), European citizens strongly advocate the necessity of functioning the Energy Union, either as a tool for promoting decarbonising economies or for increasing European energy security. Put differently, European citizens become a very important medium for advocating the significance of the Energy Union, much more than the member states' governments. These data should not be neglected by the national governments giving the fact that European citizens are the end-users of the results of European energy policy and, in that sense, are giving legitimacy to the European energy actions.

Sketching this brief history of efforts for developing supranational prerogatives in the domain of the EU's energy policy had a two-fold purpose: firstly, to inform and contextualize the process of politicization and

${ }^{10}$ These five dimensions are: energy security, solidarity and trust; a fully integrated internal energy market; energy efficiency contributing to the moderation of demand; decarbonising the economy; research, innovation and competitiveness (What is the Energy Union about, 2015). 
securitization of energy-related issues within the EU, and secondly to show gradual change of its perspective and practice from energy governance towards energy diplomacy and realizing more-integration-thanfragmentation evolution. Today, more than ever, the EU is basing its external energy relations on 'directly involving itself' in negotiating bilateral energy deals or accomplishing infrastructure projects (Herranz-Surrallés, 2016, p. 1386), contrary to its 1990s policy of creating common regulatory space. Direct negotiations between the EU and Azerbaijan and Turkmenistan over the Southern Gas Corridor presents one of those examples of pure energy diplomacy moves. Considering that the dependency is the most used keyword to describe the EU's energy state-of-play and future energy scenarios (Cotella et al., 2016, p. 39), it is not surprising when noticing that the majority of supranational efforts were, and still are, directed towards reducing EU's dependency rate from one dominant supplier and, therefore, towards promoting diversifying projects.

\section{RECENT EUROPEAN ENERGY SECURITY DYNAMICS}

According to the Copenhagen School of security studies scholars, today's Europe consists of two RSCs, each one being centred around two great powers - the EU and Russia. These two RSCs form a loose supercomplex where the EU and Russia 'are not involved enough in each other's security issues to turn "Europe" into one large RSC' (Buzan and Wæver, 2003, p. 343). This statement could be questioned considering that Buzan and Wæver' book was published in 2003 when energy relations between these two actors were not politicized (and securitized) and when security dynamics between them generally were not so much high in agendas as nowadays.

Observing the EU as the closest to the security community form, it is the most coherent regional security complex today, meaning that most of its units perceive threats in the same manner. Speaking of securitization actors who label certain phenomena as a threat to security, Buzan and Wæver gave to processes of securitization key place in defining threats to units/states within a regional security complex. ${ }^{11}$ Although there are some discrepancies between member states when it comes to marking European energy dependency from one dominant gas supplier as a threat, this paper focuses on the supranational level from where securitization moves come

${ }^{11}$ Simply said, securitization means labeling certain phenomenon as a threat to security. More on the process of securitization, see: Wæver, 1995; Buzan et al., 1998. 
undoubtedly. Either way, identification of key actors involved in European energy security dynamics and its (de)securitization moves imposes as the main methodological step. The proposed research question should be examined through two case studies that marked the most recent European energy security dynamics: the case of the Nord Stream 2 as one of the 'most controversial' energy projects and the ongoing gas dispute in the Eastern Mediterranean, both tackling key Energy Union's dimensions.

\section{The case of the Nord Stream 2 Pipeline}

Presenting a project that will lead to greater EU's dependency on Russian natural gas, the Nord Stream 2 pipeline (hereinafter NS2) remains one of the main topics of many debates. Bringing an additional $55 \mathrm{bcm}$ of gas per year to Europe (Gazprom, 2020a), this pipeline doubles the capacity of the Nord Stream 1. Although the construction of this pipeline was negotiated in 2018, tensions over its final realization do not subside almost three years later. As has been pointed out many times, the NS2 has divided the EU into supporters (led by few Western member states and their gas companies) and opponents (mostly coming from Central and Eastern Europe) (Loskot-Strachota, 2016; Šekarić, 2020). This division is mainly led by the interplay between material and geopolitical factors (de Jong et al., 2020), showing that national energy interests played significant roles. Besides, the NS2 has raised the US's attention, which is above all interested in exporting its LNG to Europe. This US's focus on the NS2 resulted in the packages of sanctions against European companies and individuals employed in its construction, ${ }^{12}$ consequently leading to the deterioration in German-USA relations. Considering one of the main goals of the established Energy Union in the form of diversifying European energy transportation routes and producers, the NS2 could be seen as a prominent obstacle. Additionally, concerns over the greater dependence from Russia and uncertainty over the Ukrainian transit route ${ }^{13}$ were intensified by the announcement of the construction of the TurkStream. ${ }^{14}$

12 The latest expansion of sanctions included 'those that provide services for vessels used in laying the final hundred miles of the project' (Morningstar et al., 2020).

${ }^{13}$ After much speculation, Ukraine and Russia signed a new agreement at the end of 2019 for the next five years of gas transit.

${ }^{14}$ The TurkStream (with an aggregate throughput capacity of $31.5 \mathrm{bcm}$ ) will connect Russian gas reserves and the Turkish gas transport network across the Black Sea 
Labeling America's behaviour on this issue as 'mafia' (Vujić, 2020, p. 3), the Bundestag openly gives support for the realization of the NS2 and places Germany as its loudest supporter. Nevertheless, a 'pipeline from Hell' (Koeljo and Grojec, 2018) has divided Europe when it comes to the political and security consequences of the NS2 and thus brought the integrative role of the Commission under the question. ${ }^{15}$ The division of European member states over this pipeline leads further to the inability of the EU to take a common stance in its energy policy, especially when considering that the completion of the project is more than $90 \%$ (Timeline, 2020). This question clearly posed an obstacle in front of the EU regarding its internal integration, and is stopping the EU's energy diplomacy efforts. As Boagert showed, the role of the European Commission is the key for the future of this project: either the Commission will lead to 'strengthening of the energy security community of the $\mathrm{EU}^{\prime}$ or failure to stop its completion will lead to 'a regression to an energy security regime with internal agreements maintaining cooperation' (2019, pp. 42-43). Its controversial background is further deepened by the statements that the main supporters are masking the costs of its cancellation by advocating that it is a 'purely commercial' project (Morningstar et al., 2020).

In the context of RSCT, when talking about the possibilities of the NS2 to transform established European regional patterns internally, it could be seen that the role of the European Commission as a key securitization actor and integration leader will be undermined in case of its completion. Therefore, total integration will still be under question. Also, strong support for its realization coming from Germany poses the question of the RSC's main actor in terms of the power criterion. However, following the steps made so far, it is expected that the Commission would still continue to carry on integration steps towards achieving a common energy voice within the EU under the Energy Union roof, even when the NS2 is realized. In any case,

and provide the rest of South and Southeast Europe with Russian natural gas (Gazprom, 2020b). This pipeline is often presented as a successor of the failed South Stream.

${ }^{15}$ Furthermore, the case of Poland could also be added to this complex equation. Namely, Poland is one of the main opponents to the NS2's completion considering that it is the loudest in securitizing this issue. However, its energy dependency on coal undermines European climate and green-energy goals to some extent and thus, the achievement of a common energy voice within the EU. Nevertheless, this calls for some future analysis. 
the NS2 certainly presents a peculiar milestone for the future of European energy integration. On the other hand, the external transformation of the RSC could be realized in the form of strengthening bonds between two complexes centred around the EU and Russia, considering that energyrelated topics are still the dominant question among all (security) others where the EU and Russia are being brought together. The realized Southern Gas Corridor, almost done NS2 and the announced TurkStream are the most significant pipelines that affect European energy security dynamics as key factors of its external rapprochement with Russia.

\section{The case of energy clash in the Eastern Mediterranean}

Northern and Western Europe seem not to be a lonely example of controversial energy-related issues. Although gas fields have not been recently discovered in the Eastern Mediterranean, recent events put them high on the agendas of Greece, Turkey, Cyprus, Egypt, Israel, Syria, and Lebanon. ${ }^{16}$ In the context of RSCT, it is important to note that Turkey is perceived as an insulator state and thus not originally being part of an established complex centred around the EU. However, some of the latest researches showed the notably bigger and more active role of Turkey when talking about European energy security, the need to revise its role of an insulator and the possibility to be part of this complex as needed (Barrinha, 2014; Luenam, 2015; Šekarić and Lazić, 2020). When it comes to energy security in the Eastern Mediterranean, Turkey is taking an increasingly assertive role (Demiryol, 2020) trying to impose itself as a regional energy hub.

As shown by Buzan and Wæver, the character of a local RSC will often be affected by historical relations such as long-standing enmities or the common cultural embrace of a civilizational area (2003, p. 45). In that sense, it is not difficult to conclude that specific historical bondages between Greece, Turkey and Cyprus and the rest of the Levant have a prominent place in its overall security dynamics. In fact, seems that these dynamics is further shaken by the recent energy clash on natural gas that took place in this area, bringing the subcomplex of the Levant closer to the EU when it comes to energy security. The planned EastMed subsea pipeline connecting Greece, Israel and Cyprus while opposing Turkey, is a further contributor

${ }^{16}$ The first three are being the most important for the EU when talking about its energy security dynamics as well as for the context of this paper. 
to this complex picture. ${ }^{17}$ What additionally complicates existing regional dynamics is the exclusion of Turkey from the EastMed Gas Forum as well as overlapping maritime claims between those states. Furthermore, the EU and the USA could be classified as supporters of this pipeline due to their strong devotion to diversify European gas suppliers and routes (Mamedov, 2020) which corresponds to the proclaimed goals of the Energy Union.

The power of energy resources not only to redefine existing regional patterns but to create new ones is a debate topic of many scholars (Ceylan and Baykara, 2020; Goldthau et al., 2020). Going beyond the statements that energy could only redefine boundaries of the existing regions, Goldthau et al. claim that energy 'fundamentally affects regionalization processes' (2020, p. 2), thus giving energy the epithet of region-building factor, testing this 'energization' process right on the example of the Eastern Mediterranean. Although this imposes some future operationalizations and research, it should not be neglected that the securitization of these gas fields put the Eastern Mediterranean on the top of the world energy map (Christou and Adamides, 2013; Goldthau and Sitter, 2020), making energy a significant factor in its classification somewhere between conflict formation and security regime.

Drawing from the description of European energy security dynamics, some predictions of its evolutions could be summarized: the maintenance of the status quo is the least likely option considering all the steps made in regard to reduce European energy dependence from one dominant supplier and a general shift in its energy policy priorities. Established regional security patterns in the case of the internal transformation seem more likely to change, especially along the line fragmentation-integration. This process of internal energy integration could be better explained as one step forward, two steps backwards. Given the fact that Germany strongly supports the realization of the NS2, while the leading role of the Commission in securitizing this issue is lagging, the RSC's main actor is somewhat questionable. Consequently, this state-of-play questions further European integration in the domain of its energy policy. However, having in mind the

${ }^{17}$ Turkish argument contra this pipeline is that the TAP pipeline is already sufficient and that Turkey is the only logical energy hub for Europe when it comes to the energy resources of the Eastern Mediterranean (Koutantou, 2020). 
development of the European energy policy from energy governance towards energy diplomacy so far and Commission's expressed efforts towards its integration as well, it is expected that the Commission would continue to act towards achieving a common energy voice under the Energy Union umbrella. Employed theoretical guidelines further suggest that the external transformation of the RSC could be realized in the form of strengthening bonds between two complexes centred around the EU and Russia as best shown by the realized Southern Gas Corridor, almost done NS2 and the announced TurkStream. Besides, the role of Turkey as an insulator state is also questioned, and the possibility of natural gas to create new regional patterns in the Eastern Mediterranean is analysed. The possibility of creating a new energy-driven subcomplex is not excluded, which brings the EU's periphery closer to the Levant subcomplex. As could be seen, both internal and external elements of European energy security dynamics are so interlinked and overlapping that could not be analysed separately, making energy issues increasingly becoming part of European regional security architecture.

\section{CONCLUSION}

Traditionally, the EU's energy policy was linked to the concept of energy governance and its efforts to create a common regulatory space and to export rules and values beyond its borders. Today, the EU is taking a mixture of energy governance and energy diplomacy, inclining towards the latter one. This subtle shift has led to the greater EU's involvement within the member states' energy policies and security-driven decision-making. In addition, very vivid energy security dynamics in the last two decades in the EU showed increased possibilities towards the transformation of its established security patterns, both internally and externally. Whether talking about the core of the EU or its periphery, both are equally involved in energy security concerns. While the external transformation is likely to occur only through the oncoming of two European RSCs, its internal integration shows some positive trends, but still strongly facing some obstacles such as different interests of the member states and the variety of their energy mix. Many energy-related topics are still in the member states' hands, but the common energy policy is still developing and has achieved some progress compared to the 1980s and 1990s energy picture.

Whether talking about reshaping region's boundaries or creating completely new regional forms and processes, energy resources do have 
transformative potential. With the paradigm shift from the market-based approach and competitiveness towards forms of energy diplomacy, by strongly advocating diversifying projects and strengthening supranational competencies within energy security issues, the EU gave a peculiar geopolitical and security label to its energy policy. The external transformation in the context of energy security ultimately leads to the approaching of two complexes (the one being centred around the EU and the one being centred around Russia) and the formation of a stronger supercomplex. Also, the internal transformation of established European regional security patterns seems likely to occur, particularly along the line of fragmentation-integration. However, this depends on the overall security context and the way of implementation of the proposed Energy Union's goals, so the future scenarios of its application need to be examined and its effects evaluated.

\section{REFERENCES}

Adamides, C., \& Christou, O. (2015). Energy security and the transformation of regional securitization relations in the Eastern Mediterranean, in: S. Katsikides \& P. I. Koktsidis (Eds.), Societies in Transition (pp. 189-205). Cham, Springer.

Avlichou, A. (2017). European Energy Union: Continuity or Change? Leiden, Universiteit Leiden.

Barrinha, A. (2014). The ambitious insulator: revisiting Turkey's position in Regional Security Complex Theory, Mediterranean Politics, 19(2), pp. 165-182.

Boersma, T. \& Goldthau, A. (2017). Wither the EU's Market Making Project in Energy: From Liberalization to Securitization, in: S. S. Andersen, A. Goldthau \& N. Sitter (Eds.), Energy Union: Europe's New Liberal Mercantilism? (pp. 99-113). London, Palgrave Macmillan.

Bogaert, T. (2019). Rock the Pipeline: A Strategic Analysis of the Nord Stream 2 Conundrum. Brussel, Vrije Universiteit Brussel.

Buzan, B. \& Wæver, O. (2003). Regions and powers: the structure of international security. Cambridge, Cambridge University Press.

Buzan, B., Wæver, O. \& De Wilde, J. (1998). Security: A new framework for analysis. London, Lynne Rienner Publishers.

Ceylan, T.E. \& Baykara, S.T. (2020). Energy in the Eastern Mediterranean: A Shaping Factor for Regional Security or Inesecurity, in: H. Babacan (Ed.), 
Academic Studies in Social, Human and Administrative Sciences (pp. 333359). Ankara, Gece Publishing.

Christou, O., \& Adamides, C. (2013). Energy securitization and desecuritization in the New Middle East, Security Dialogue, 44(5-6), pp. 507-522.

Cotella, G., Crivello, S. \& Karatayev, M. (2016). European Union energy policy evolutionary patterns, in: P. Lombardi \& M. Gruenig (Eds.), Lowcarbon Energy Security from a European Perspective (pp. 13-42). London, Academic Press.

de Jong, M., Van de Graaf, T. \& Haesebrouck, T. (2020). A matter of preference: Taking sides on the Nord Stream 2 gas pipeline project, Journal of Contemporary European Studies, pp. 1-14.

Demiryol, T. (2020, November). Beyond Energy: The Geopolitical Determinants of Turkey's Mediterranean Policy. The Eastern Mediterranean and Regional Security: A Transatlantic Trialogue series, pp. 2-10.

EP. (2020). The von der Leyen Commission's priorities for 2019-2024, Briefing, European Parliament, Brussels.

EU imports of energy products - recent developments. (2020, October 15), retrieved from https://ec.europa.eu/eurostat/statistics-explained/ index.php?title=EU_imports_of_energy_products_-_recent_develop ments\&oldid=478148. Accessed 12 December 2020.

EU. (2007). Treaty of Lisbon: Amending the Treaty on European Union and the Treaty establishing the European Community, (2007/C 306/01), Official Journal of the European Union, Vol. 50, 17 December.

Franza, L. \& Van Der Linde, C. (2017). Geopolitics and the Foreign Policy Dimension of EU Energy Security, in: S. S. Andersen, A. Goldthau \& N. Sitter (Eds.), Energy Union: Europe's New Liberal Mercantilism? (pp. 8598). London, Palgrave Macmillan.

Gazprom. (2020a). Nord Stream 2, retrieved from https:/ / www.gazprom. com/projects/nord-stream2/. Accessed 21 December 2020.

Gazprom. (2020b). TurkStream, retrieved from https:/ /www.gazprom.com /projects/turk-stream/. Accessed 21 December 2020.

Goldthau, A. \& Sitter, N. (2020). Horses for courses. The roles of IPE and Global Public Policy is global energy research, Policy and Society, 40(1), pp. 1-18.

Goldthau, A. C., Richert, J., \& Stetter, S. (2020). Leviathan Awakens: Gas Finds, Energy Governance, and the Emergence of the Eastern 
Mediterranean as a Geopolitical Region. Review of Policy Research, pp. 119. doi: 10.1111/ropr.12387

Herranz-Surrallés, A. (2016). An emerging EU energy diplomacy? Discursive shifts, enduring practices, Journal of European Public Policy, 23(9), pp. 1386-1405.

Herranz-Surrallés, A., Solorio, I., \& Fairbrass, J. (2020). Renegotiating authority in the Energy Union: A Framework for Analysis, Journal of European Integration, 42(1), pp. 1-17.

Kirchner, E., \& Berk, C. (2010). European Energy Security Co $\square$ operation: Between Amity and Enmity, JCMS: Journal of Common Market Studies, 48(4), pp. 859-880.

Knodt, M., \& Ringel, M. (2020). European Union energy policy - a discourse perspective, in: M. Knodt \& J. Kemmerzell (Eds.), Handbook of energy governance in Europe (published online first). Cham, Springer.

Knodt, M., Piefer, N., \& Mueller, F. (Eds.). (2015). Challenges of EU external energy governance towards emerging powers. Ashgate, Farnham/ Burlington.

Koeljo, K. \& Grojec, V. (2018, September 21). Gasovod iz pakla? Severni tok 2 i zašto je toliko sporan? [A Pipeline from Hell? The Nord Stream 2 and why is it so controversial]. Radio Slobodna Evropa, retrieved from https:/ / www.slobodnaevropa.org/a/severni-tok-2-i-za\%C5\%A1to-jetoliko-sporan-/29498221.html. Accessed 5 December 2020.

Koutantou, A. (2020, January 2). Greece, Israel, Cyprus sign EastMed gas pipeline deal. Reuters, retrieved from https://www.reuters.com/ article/us-greece-cyprus-israel-pipeline/greece-israel-cyprus-signeastmed-gas-pipeline-deal-idUSKBN1Z10R5. Accessed 21 December 2020.

Lavenex, S., \& Schimmelfennig, F. (2009). EU rules beyond EU borders: theorizing external governance in European politics, Journal of European public policy, 16(6), pp. 791-812.

Lipovac, M. (2016). Nacionalna bezbednost Republike Srbije u regionalnom bezbednosnom potkompleksu Zapadni Balkan [The Republic of Serbia National Security in the Western Balkans Regional Security Complex]. Belgrade, Faculty of Security Studies.

Loskot-Strachota, A. (2016). Nord Stream 2: policy dilemmas and the future of EU gas market. Retrieved from https:/ / www.europeangashub.com/wpcontent/uploads/attach_580.pdf 
Luenam, J. (2015). Rethinking Turkey's position in the Middle eastern regional security complex: from insulator to regional leader?. Cairo, The American University in Cairo.

Mamedov, R. (2020, December 20). The Energy Sector, Competition and Security in the Eastern Mediterranean. Modern Diplomacy, retrieved from https:/ / moderndiplomacy.eu/2020/12/20/the-energy-sectorcompetition-and-security-in-the-eastern-mediterranean/. Accessed 21 December 2020.

Mišík, M. (2019). External Energy Security in the European Union: Small Member States' Perspective. London, Routledge.

Morningstar, R.L., Fried, D. \& Khakova, O. (2020, December 18). Reinforcing transatlantic ties amidst Nord Stream 2 sanctions: A way forward, retrieved from https://www.atlanticcouncil.org/blogs/energysource/ reinforcing-transatlantic-ties-amidst-nord-stream-2-sanctions-a-wayforward/. Accessed 21 December 2020.

Prange-Gstöhl, H. (2009). Enlarging the EU's internal energy market: Why would third countries accept EU rule export?, Energy Policy, 37(12), pp. 5296-5303.

Šefčovič, M. (2015, February 27). Driving the EU forward: The Energy Union, retrieved from https:/ / ec.europa.eu/commission/ presscorner/detail/ en/SPEECH_15_4520. Accessed 15 December 2020.

Šekarić, N. (2020). Evropska energetska bezbednost: slučaj Severnog toka 2 [European Energy Security: A Case Study of the Nord Stream 2], Međunarodna politika, LXXI(1179-80), pp. 119-138.

Šekarić, N. \& Lazić, V. (2020). The Western Balkans' Energy Security in a Triangle: The Role of the EU, Russia and Turkey, in: A. Jović-Lazić \& A. Troude (Eds.), Security Challenges and the Place of the Balkans and Serbia in a Changing World (pp. 119-133). Belgrade, Institute of International Politics and Economics \& Faculty of Security Studies.

Szulecki, K., \& Westphal, K. (2018). Taking Security Seriously in EU Energy Governance: Crimean Shock and the Energy Union, in: K. Szulecki (Ed.), Energy Security in Europe: Divergent Perceptions and Policy Challenges (pp. 177-202). Cham, Palgrave Macmillan.

Tarnai, Z. (2018). Building A Common European Energy Policy: Drivers of Negative and Positive Energy Policy Integration in the European Union. Budapest, Central European University.

Tichý, L. (2019). EU-Russia Energy Relations: A Discursive Approach. Cham, Springer. 
Timeline: Nord Stream 2 Gas Pipeline's Difficult Birth. (2020, December 15), retrieved from https://www.oedigital.com/news/483906-timelinenord-stream-2-gas-pipeline-s-difficult-birth. Accessed 21 December 2020.

Tosun, J., \& Mišić, M. (2020). Conferring authority in the European Union: citizens' policy priorities for the European Energy Union, Journal of European Integration, 42(1), pp. 19-38.

Vujić, T. (2020, November 28). Bundestag: Amerika se protiv 'Severnog toka 2 ' ponaša kao 'mafija' [Bundestag: America is acting as 'mafia' against the Nord Stream 2]. Politika, p. 3.

Wæver, O. (1995). Securitization and Desecuritization, in: R. D. Lipschutz (Ed), On Security (pp. 46-87). New York, Columbia University Press.

What is the Energy Union about? (2015), retrieved from https:/ / ec.europa. eu/eurostat/cache/digpub/energy/2019/bloc-1.html. Accessed 7 November 2020.

Youngs, R. (2011). Foreign Policy and Energy Security: Markets, Pipelines, and Politics, in: V. L. Birchfield \& J. S. Duffield (Eds.), Toward a Common European Union Energy Policy (pp. 41-60). New York, Palgrave Macmillan. 